
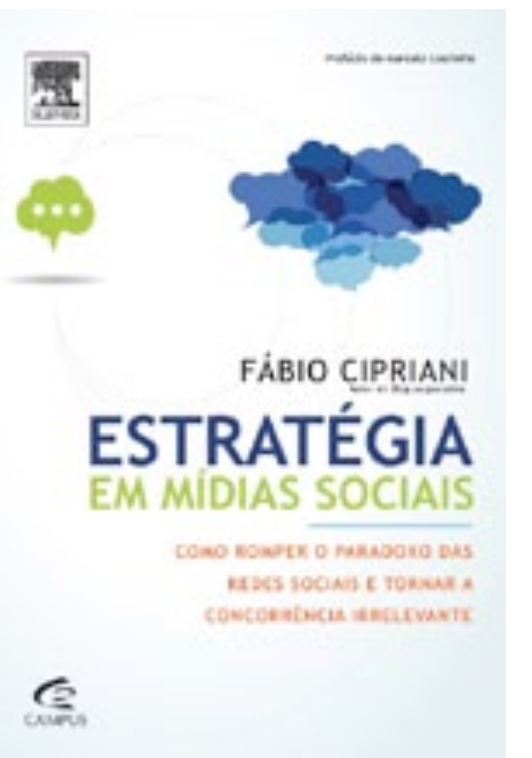

\title{
Fábio Cipriani
}

Estratégia em mídias sociais: como romper o paradoxo das redes sociais e tornar a concorrência irrelevante

Rio de Janeiro: Elsevier;

São Paulo: Deloitte, 2011

$184 \mathrm{p}$.

Resenhado por:

\section{Carolina Frazon Terra}

- Doutora e mestre em Ciências da Comunicação pela Escola de Comunicações e Artes da Universidade de São Paulo (ECA-USP)

- Especialista em Gestão Estratégica da Comunicação Organizacional e de Relações Públicas pela ECA-USP

- Graduada em Comunicação Social - Relações Públicas pela Universidade Estadual Paulista (Unesp)

- Consultora de mídias sociais e professora dos cursos de Relações Públicas e Publicidade e Propaganda da Fundação Escola de Comércio Álvares Penteado (Fecap)

- $\quad$ Editora do blog RPalavreando (http://rpalavreando.com.br)

- Autora dos livros Mídias sociais...e agora? e Blogs corporativos: modismo ou tendência?

- E-mail: carolinaterra@gmail.com 


\section{Entendendo as mídias sociais}

\section{Understanding the social media}

\section{Entendiendo los medios sociales}

$\mathbf{F}$

ábio Cipriani é um profissional de mercado com experiência na consultoria de estratégia, business e comunicação digital para organizações. Em seu segundo livro, o autor inicia a jornada explicando conceitos relacionados à comunicação no ambiente digital, como economia de rede, de internet, mídias sociais, redes sociais, comunidades virtuais e diálogo e demonstra a relação entre eles em um diagrama muito esclarecedor (p. 4).

O autor também explica ao leitor conceitos básicos do universo digital, tais como widgets, RSS, tags, wikis, fóruns de discussão etc. Além disso, a primeira parte do livro busca contextualizar o leitor sobre o que é o ambiente digital e que conceitos fazem parte desse cenário.

O capítulo dois esclarece quem é o novo consumidor social: é um usuário ativo das tecnologias digitais, que espera da experiência on-line algo melhor do que da off-line; que compartilha conteúdos por meio de seus perfis em mídias sociais; que opina e confia em recomendações feitas on-line; que lê e critica produtos e serviços; que cria rankings; que procura suporte para se conectar a pessoas parecidas ou que têm as mesmas ideias; e que, em resumo, utiliza novos canais on-line e novas ferramentas de comunicação.

Nos capítulos três e quatro, o autor explica como a expectativa do consumidor, combinada ao atendimento dessa demanda, resulta na sua satisfação. Ele reforça que a intenção de influenciar, característica muito presente nas mídias sociais, acarreta a necessidade de monitoramento dessa mídia.

Fábio também se detém a explanar sobre a experiência do cliente e o quanto ela é decisiva para uma marca,um produto ou um serviço ter uma boa imagem ou reputação nas redes. Um cliente satisfeito ajuda a vender mais. $E$, pensando exatamente nessa lógica, traz exemplos de social commerce, um tipo de comércio que se vale dos usuários comuns como força de vendas de uma organização, sendo esta a principal origem das vendas ou não. Nesse sentido, também recomenda sites de pagamento, acompanhamento e recebimento de mercadorias. $E$, como não poderia deixar de ser, nesse processo, há também a opinião do consumidor, consolidada em sites como Reclame Aqui ou em redes sociais proprietárias como IdeaStorm.

As redes sociais colaborativas, como redesignme.com, hollrr.com, mystarbuscksidea, ideasculture.com etc., também são alvo dos estudos de Fábio, que chama esse movimento de inovação colaborativa, pela possibilidade que tais ferramentas trazem tanto a usuários quanto a organizações 
de criarem novos produtos e compartilharem tais soluções com comunidades de interessados, por vezes com recompensas para isso.

Outro conceito bastante trabalhado pelo autor é o de customer relationship management (CRM) social, que une as pontas de negócio (business, atendimento ao cliente e comunicação com foco em relacionamento) e de agregação social.

A segunda ate do livro traz um pouco de teoria sobre redes sociais. Fábio sinaliza que os conceitos derivam da matemática e da sociologia, existindo desde antes do surgimento da internet. Para se começar uma estratégia em mídias sociais, o primeiro passo, na visão do autor, é definir objetivos e abordagens. Para cada um desses elementos, ele apresenta exemplos de métricas que podem calcular o impacto das ações.

Para a gestão de um projeto de mídias sociais, Fábio recomenda que se trace um plano de trabalho, bem como se monitorem e ajustem as iniciativas.

Um dos assuntos de maior interesse, nos últimos tempos tem sido como mensurar as ações de mídias sociais, como quantificá-las e como qualificá-las. Pensando nisso, Cipriani dedicou um capítulo ao retorno sobre o investimento (ROI) de mídias sociais. Ele traz um indicador chamado net promoter score (NPS), criado por Fred Reichheld, o qual é obtido tomando a porcentagem de clientes que recomendariam sua empresa (os promotores) e subtraindo o percentual dos que não a recomendariam (os detratores), sem levar em conta os que se mostraram neutros. Além de discorrer sobre o indicador, Fábio destaca a importância de se medir o capital social de uma organização, uma vez que este passa a ser a referência de reconhecimento que se busca na relação entre pessoas. E, para mensurar o capital social, é preciso medir a reputação, o engajamento, o alcance das ideias, recomendações, ou seja, confiança, comunicação e expertise.

Por fim, Fábio analisa uma série de cases de empresas reais e também sugere uma metodologia para execução das iniciativas em mídias sociais e um guia de bolso sobre como ter uma estratégia bem-sucedida.

O livro destina-se a estudantes e profissionais de comunicação que desejam entender o cenário da comunicação digital e conhecer um pouco do ferramental disponível para aplicação prática das mídias sociais. 